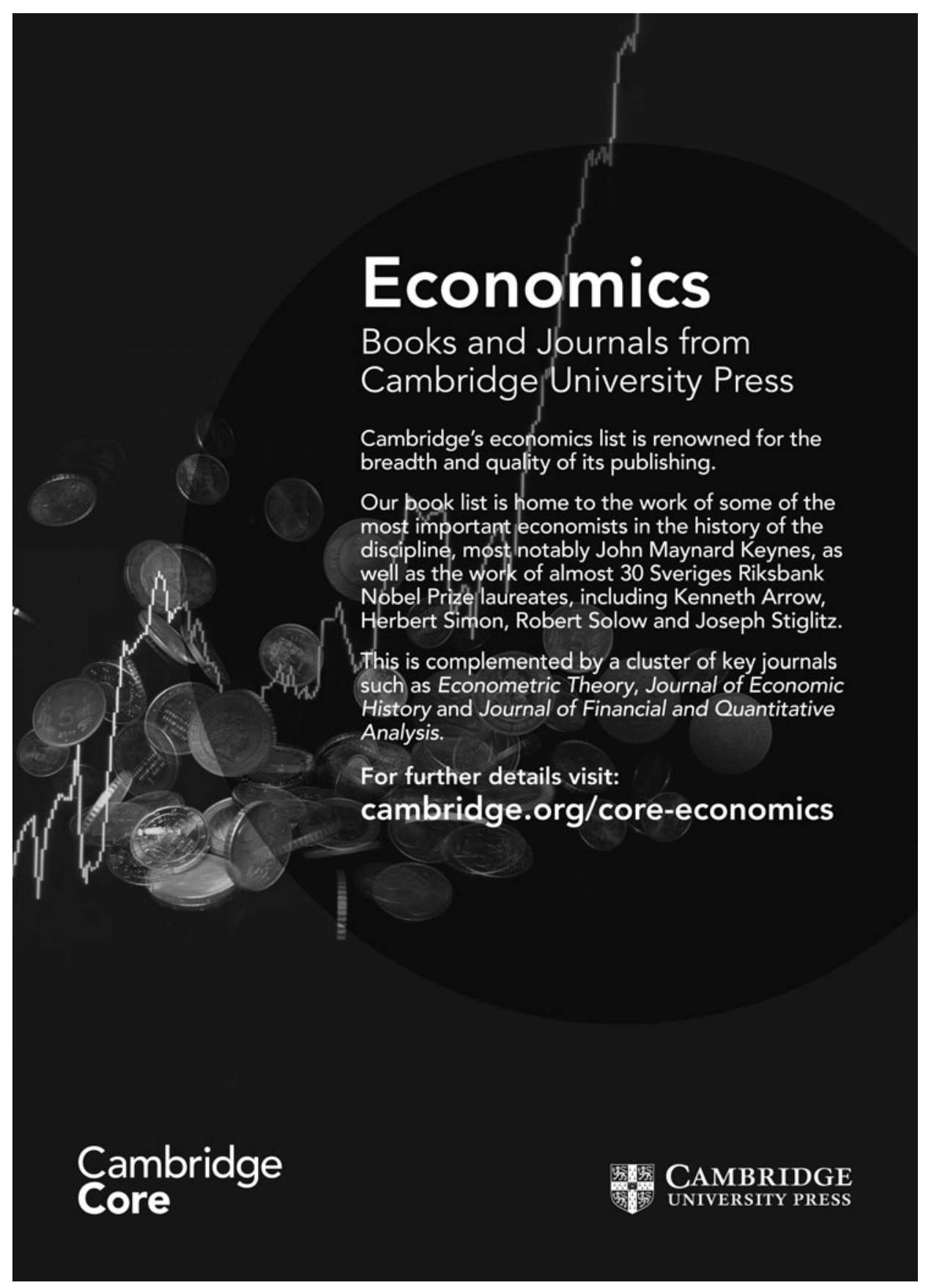




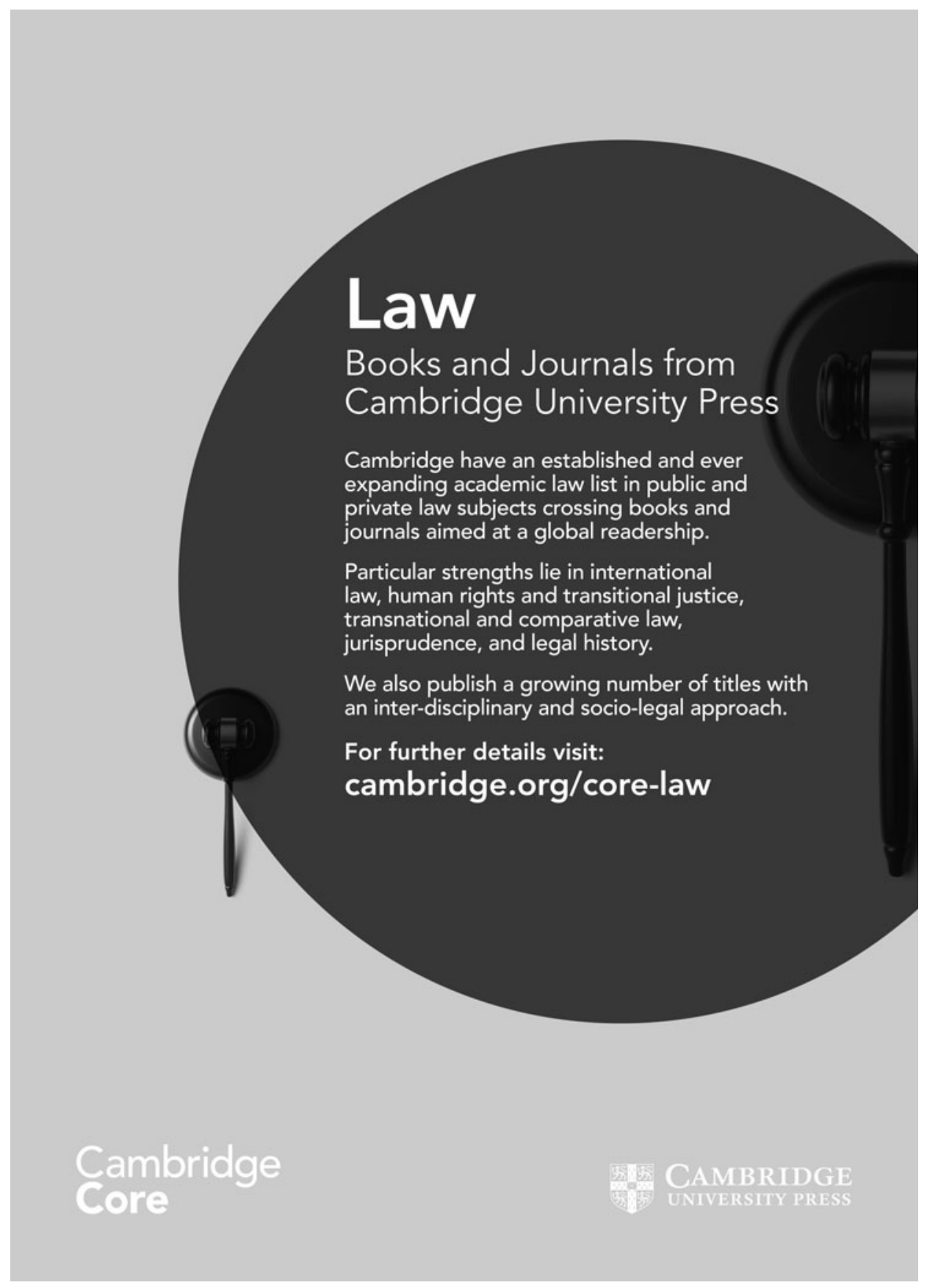




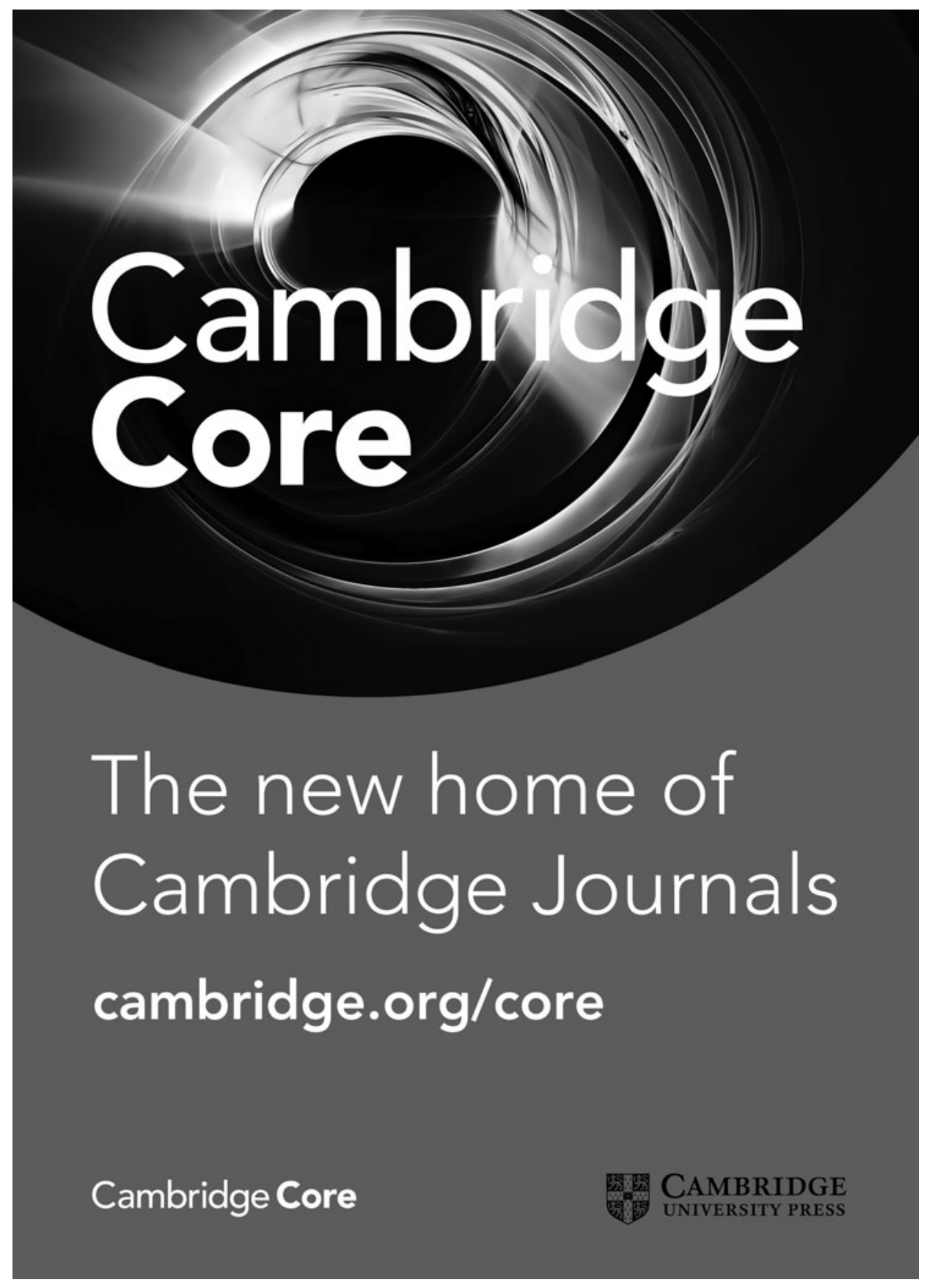




\section{WORLD TRADE REVIEW}

\section{Subscriptions}

World Trade Review (ISSN 1474-7456) is published four times a year in January, April, July and October. Four parts form a volume.

The 2017 subscription price (excluding VAT) of a volume, which includes print and electronic access, is $£ 340.00$ (US $\$ 608.00$ in USA, Canada and Mexico); $£ 40.00$ (US \$63.00) for individuals, which includes print only, ordering direct from the publishers and certifying that the journal is for their personal use. The electronic-only price available to institutional subscribers is $£ 290.00$ (US \$506.00 in USA, Canada and Mexico). Single parts are $£ 94.00$ net (US $\$ 162.00$ in USA, Canada and Mexico) plus postage. EU subscribers (outside the UK) who are not registered for VAT should add VAT at their country's rate. VAT registered members should provide their VAT registration number. Japanese prices for institutions (including ASP delivery) are available from Kinokuniya Company Ltd, P.O. Box 55, Chitose, Tokyo 156, Japan.

Orders, which must be accompanied by payment, may be sent to a bookseller, subscription agent or direct to the publisher: Cambridge University Press, Journals Fulfillment Department, UPH, Shaftesbury Road, Cambridge CB2 8BS, UK; or in the USA, Canada and Mexico: Cambridge University Press, Journals Fulfillment Department, 1 Liberty Plaza, Floor 20, New York, NY 10006, USA. Periodicals postage paid at New York, NY and at additional mailing offices.

\section{Copying}

This journal is registered with the Copyright Clearance Center, 222 Rosewood Drive, Danvers, MA 01923, USA. Organizations in the USA who are also registered with the C.C.C. may, therefore copy material (beyond the limits permitted by, sections 107 and 108 of U.S. Copyright law) subject to payment to the C.C.C of the per copy fee of $\$ 15.00$. This consent does not extend to multiple copying for promotional or commercial purposes. Code 1474-7456/16. ISI Tear Sheet Service, 3501 Market Street, Philadelphia, PA 19104, USA, is authorized to supply single copies of separate articles for private use only. Organizations authorized by the Copyright Licensing Agency may also copy, material subject to the usual conditions. For all other use, permission should be sought from Cambridge or from the American Branch of Cambridge University Press.

World Trade Review is included on Cambridge Core. For information on other Press titles go to cambridge.org/.

Enquiries about advertising should be sent to the Journal's Promotion Department of the Cambridge or American Branch of Cambridge University Press.

This journal issue has been printed on FSC-certified paper and cover board. FSC is an independent, non-governmental, not-for-profit organization established to promote the responsible management of the world's forests. Please see www.fsc.org for information.

(C) Cambridge University Press 2017

Printed in the UK by Bell \& Bain Ltd

ISSN $1474-7456$ 


\title{
WORLD TRADE REVIEW
}

\author{
Guest editors: Chad P. Bown and Petros C. Mavroidis
}

WTO Dispute Settlement in 2015: Going Strong after Two

Decades

Chad P. Bown and Petros C. Mavroidis

China-HP-SSST: Last Part of Growing Pains?

Dukgeun Ahn And MaurizIo ZanardI

US-Shrimp II (Vietnam): Dubious Application of Anti-Dumping Duties - Should Have Used Safeguards

Ben ZISSIMOS AND Jan Wouters

China-GOES (Article 21.5): Time to Clarify the Standard for Price Suppression and Price Depression in AD/CVD Investigations

JULIA QIN AND HyLKE VANDENBUSSCHE

Does Safeguards Need Saving? Lessons from the

Ukraine-Passenger Cars Dispute

AreVIK GNUTZMAnN-MkRTCHYAN AND SIMON LESTER

Foot-and-Mouth Disease and Argentina's Beef Exports: The WTO's US-Animals Dispute

Chad P. Bown and Jennifer A. Hilliman

Trade and Agricultural Disease: Import Restrictions in the Wake of the India-Agricultural Products Dispute

Kamal SagGi and Mark Wu

FTA Law in WTO Dispute Settlement: Peru-Additional Duty and the Fragmentation of Trade Law

Gregory ShafFer and L. Alan Winters

Risk and Regulatory Calibration: WTO Compliance Review of the US Dolphin-Safe Tuna Labeling Regime

Cary Coglianese and André SAPIR

Argentina-Import Measures: How a Porsche is worth Peanuts PaOla Conconi ANd Harm SChepel

US-COOL Retaliation: The WTO's Article 22.6 Arbitration

Chad P. Bown and Rachel Brewster

Ask for the Moon, Settle for the Stars: What is a Reasonable Period to Comply with WTO Awards?

Petros C. Mavroidis, Niall Meagher, Thomas J. Prusa, and Tatiana Yanguas

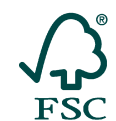

FSC 